\title{
Financial Constraints and Firm Capital Structure in Kenya
}

\author{
Benard Kipyegon Kirui ${ }^{1,2} \&$ Seth Omondi Gor ${ }^{1}$ \\ ${ }^{1}$ School of Economics, University of Nairobi, Nairobi, Kenya \\ ${ }^{2}$ Strategy, Innovation and Risk Management Department, Kenya Revenue Authority, Nairobi, Kenya \\ Correspondence: Kirui, P.O Box 53143, 00200, Nairobi, Kenya. Tel: 254-0722-694-806. E-mail: \\ bkkirui@gmail.com
}

Received: November 6, 2017

Accepted: November 30, 2017

Online Published: December 15, 2017

doi:10.5539/ijef.v10n1p177

URL: https://doi.org/10.5539/ijef.v10n1p177

\begin{abstract}
Empirical evidence suggests that capital structure varies across firms facing different levels of information asymmetry, however, this evidence contradict the prediction of pecking order hypothesis. Although debt capacity constraints offer some explanation for this discrepancy, it fails to explain the behavior of small high growth firms who do not issue debt even with no debt capacity constraints. Against this backdrop, this study investigated the effects of financial constraints on firm capital structure in Kenya. This was implemented by interacting a financial constraints dummy with the right-hand side variables of pecking order test equation to allow for any variation of capital structure across financial constraints regimes. The results show that constrained firms use less internal funds and have less cash than unconstrained firms. Pecking order theory was not supported. However, allowing financial constraints regimes in pecking order equation improved the fit of the model and produced results that are consistent with pecking order prediction. Financing behavior varies with financial constraints status. The wider the wedge between the cost of debt and the opportunity cost of internal funds, the higher the value transferred to debt-holders and the lower the debt utilization. To improve firm access to capital, policies should be geared towards reducing the wedge between the cost of external and internal funds.
\end{abstract}

Keywords: financial constraints, manufacturing, investment, capital structure, Kenya

\section{Introduction}

Empirical evidence suggests that capital structure varies across firms facing different levels of information asymmetry (Brown, Fazzari, \& Petersen, 2009), however, this evidence contradict the prediction of pecking order hypothesis. It holds for the subset of firms with less informational problem and vice versa. Specifically, pecking order hypothesis predicts financing behavior of large firms (Frank et al., 2003) and fails for small low-leverage growth firms (Fama \& French, 2002). Attempts to reconcile the theory to empirical findings have considered debt capacity constraints (Note 1 ) documenting evidence that debt capacity constrained firms tend to issue equity whenever the need for external capital arises. But even with no debt capacity constraints, small high growth firms do not follow pecking order hypothesis (Fama \& French, 2002). Consequently, it is natural to ask: what explains the reversal of predictions of pecking order theory for firms under different levels of information asymmetry and that are not debt capacity constrained (Note 2)?

In view of the foregoing, this study investigated the effects of financial constraints on firm capital structure in Kenya. Specifically, this study investigated the effects of financial constraints on pecking order hypothesis and determined how well financial constraints explain pecking order theory reversal for small firms. These objectives were implemented by interacting a financial constraints dummy with the right-hand side variables of pecking order test equation to allow for any variation of capital structure across financial constraints regimes. Firms variation in debt issues was then used to identify factors leading to pecking order theory reversal.

This study made two key contributions. First, it contributed methodologically in testing of pecking order theory in the presence of regimes. An approach which interact the regime variable with the right-hand side variables of a pecking order equation was employed to test pecking order theory; a departure from earlier work such as Lemmon and Zender (2010). Allowing financial constraints regimes in pecking order equation improved the fit of the pecking order equation and produced results that are consistent with pecking order prediction. Second, this study is related to emerging literature on explaining pecking order theory reversal such as Lemmon and Zender (2010) and Yang (2014). However, unlike Lemmon and Zender (2010) who used debt capacity constraints to 
augment capital structure equation and Yang (2014) who studied financial constraints and capital structure in a more general form (Note 3), this study explicitly introduces financial constraints regimes in pecking order equation. Specifically, this study is similar in spirit to the work of Lemmon and Zender (2010), however, instead of augmenting the pecking order equation, this study allowed for financial constraints regimes and relied on the marginal effects to test for the existence and the effects of financial constraints on financing behavior.

The findings of this study are important for two reasons. First, determining the effects of financial constraints on firm capital structure and hence the cost of external funds is important in shaping the interpretation of the observed investment-cash flows sensitivities in the financial constraints literature. Second, determining the form in which financial constraints take is important in developing policies to alleviate constraints on access to external capital. Moreover, undertanding how financial constraints affect firm's financing decision, provides candidate explanation to two key questions in corporate finance. These questions are: what causes violation of pecking order theory? and why do not small high growth firms issue debt even when they are not debt capacity constrained?

\section{Related Literature}

\subsection{Theoretical Literature}

Theoretical analysis of capital structure began with Modigliani and Miller (1958) capital structure irrelevance theory. This theory states that in a perfect capital market, the cost of capital remains constant as debt to equity ratio changes. The cost of capital does not change when leverage changes since any gain accruing to the firm from the use of relatively cheaper debt will be offset by the increase in the cost of equity. Thus, the cost of capital and hence the value of the firm is independent of capital structure of the firm. This model is derived under the assumption of perfect capital markets; however, capital markets are likely to be imperfect due to presence of taxes, imperfect information among other factors. As a result, taxes were introduced into the model in 1963 by Modigliani and Miller (1963).

With the introduction of taxes, the model predicts that firms should use 100 percent debt financing due to interest tax shield. However, in practice firms used a mixture of debt and equity. At the core of this was the question, what prevents firms from using a 100 percent debt capital. This question was addressed by trade-off theory of capital structure. The trade-off theory of capital structure argues that the interest tax shield of debt is offset by costs of financial distress and the interactions of these two generate an optimal capital structure (Myers, 1977).

All these models assume perfect information; hence they are not suitable for the analysis of capital structure under information asymmetry. In addition, these theoretical models explain the level of debt and equity in a firm's capital structure and often do not discuss the evolution of capital structure (Note 4), and hence cannot be interpreted as models of financing behavior. Models of capital structure based on information asymmetry emerged in late 1970s (see for instance; Jensen \& Meckling, 1976; Ross, 1977) and early 1980s (see for instance; Myers, 1984; Myers \& Majluf, 1984)

The most influential of these models is the pecking order hypothesis due to Myers (1984) and Myers and Majluf (1984). This model emphasized asymmetric information between managers and less informed outside investors, which causes outside investors to discount new and existing risky securities when firms attempt to issue risky securities. Asymmetric information causes firms to prefer internal finances to external capital, and in case internal finances are inadequate to prefer low risk debt to high-risk debt, and to prefer high-risk debt to equity. The cumulative hierarchical financing over time generates the capital structure and hence the firm has no optimal capital structure (Myers, 1984). If informational problem looms large for some firms, then pecking order predicted values should differ across firms' grouped using informational asymmetry status. This, in addition to the interpretation of this model as one of financing behavior, informed the choice of this model for evaluation of the impact of information asymmetry and hence financial constraints on firm capital structure decision.

\subsection{Empirical Literature}

This study builds on empirical literature on capital structure that has considered information asymmetry. Of primary interest in this study are the differences in the financing behavior of firms under different level of information asymmetry. Research interest on financing decisions and investment decisions date back to as early as 1930s. However, systematic analysis began in 1950s with the work of Modigliani and Miller (1958). One of the conclusions of Modigliani and Miller (1958), the independence of financing and investment decisions in a perfect capital market, motivated this study. Whether financing and investment decisions are independent or not, depends on the level of capital market imperfections the firm faces. Capital markets will be imperfect if informational problem looms large and therefore financing and investment decisions cannot be independent. 
In assessing the impact of financial constraints on firm investment, Bond and Meghir (1994) used Euler investment equation that captures the independence of financing and investment decisions. Independence of financing and investment decisions means absence of imperfections in capital markets. Based on this, firms can be dichotomized into two groups; where investment and financing decisions are independent on one hand and where they are not, on the other. In this regard, firms under the two regimes should behave differently in terms of financing and investment. Despite this possibility and evidence from financial constraints literature that firms facing different levels of information asymmetry behave differently, much of the literature on capital structure use representative firm framework.

Brown et al. (2009) documented evidence that young firms in Research and Development sector bypass debt to issue equity once they exhaust internal finances. Therefore, these firms have a financing hierarchy that consists almost entirely of internal finance and equity finance. The inclusion of age (young) in their work needs to be emphasized. Age has been used as a proxy of information asymmetry or financial constraints; therefore, it stresses how differences in information asymmetry affect firm financing behavior. This study differs from the work of Brown et al. (2009) in two respects; the latter focused only on young firms in the Research and Development sector while this study considers firms in the manufacturing sector regardless of age. Second, they sought to identify financial factors that drive growth in Research and Development sector. In contrast, this study examines the effects of information asymmetry and hence financial constraints on firm capital structure.

Similar evidence of violation of pecking order prediction were documented by Fama and French (2002) and Frank and Goyal (2003). Using data on publicly traded American firms for 1971 to 1998, Frank and Goyal (2003) found that net equity issues track the financing deficit more closely than do net debt issues, however, when they separated their sample based on size; they found that pecking order only hold for a subset of their sample constituting of large firms. Similar evidence was documented by Fama and French (2002) who observed large equity issues among small low-leverage growth firms. According to Fama and French (2002) these firms preserve low-risk debt capacity to finance future growth by issuing equity instead of debt thereby violating the pecking order theory.

These findings are in sharp contrast to the pecking order theory which predicts that debt issues should track financing deficit and this relationship should be stronger for small firms than for large ones. Unlike large established firms, small firms face more informational problem and hence equity is more expensive than debt for these firms. Thus far, age and size have emerged as important factors in firm financing behavior. This is in line with earlier evidence such as Hennessy and Whited (2007), who argued that size of the firm and the wedge between the cost of internal finance and external capital are linked.

This study complements earlier attempts to reconcile the theory to empirical findings which include Lemmon and Zender (2010) and Yang (2014). Lemmon and Zender (2010) divided firms using debt capacity constraints into two; those with debt rating are debt capacity unconstrained and those without debt rating are debt capacity constrained. They found evidence in support of pecking order hypothesis with a large coefficient of financing deficit for firms facing no debt capacity constraints than for firms facing debt capacity constraints. They also provided evidence that debt capacity constrained firms use equity to finance their deficits.

Yang (2014) examined the relationship between financial constraints and capital structure, although in a more general form that cannot be interpreted in the context of pecking order theory. In addition, Yang (2014) explicitly modeled debt capacity and equity constraints effectively leaving out the role of internal markets (see: Lamont, 1997, for the importance of internal capital markets). Hence, this model like that of Lemmon and Zender (2010) cannot account for small high growth firms that do not issue debt, even when they are not debt capacity constrained.

This study also relates methodologically to the literature on pecking order hypothesis (Myers, 1984; Myers \& Majluf, 1984). Shyam-Sunder and Myers (1999) developed testable predictions for pecking order hypothesis. The prediction is that use of external capital is driven by internal financing deficit, that is, investment less internally generated cash flows. They applied it to 157 firms over the period 1971 to 1989 and found strong evidence in support of pecking order hypothesis, however, with low statistical power.

This approach was, however, criticized by Chirinko and Singha (2000) who argued that the approach could be unable to detect violations to the pecking order hypothesis such as those identified by Brown et al. (2009). As a result, Frank and Goyal (2003) used a nested model, which combines Shyam-Sunder and Myers (1999) model and conventional factors proposed by Rajan and Zingales (1995) to test the pecking order hypothesis. If pecking order hypothesis holds, then conventional variables should not matter. In contrast, their finding showed that financing deficit does not wipe out the effects of conventional factors for their entire sample. 
Shyam-Sunder and Myers (1999), unlike this study, used representative firm framework. This study is similar to Frank and Goyal (2003) in the use of conventional variables and separation of the sample using proxies of informational problem. But, unlike Frank and Goyal (2003) who focused on the differences in capital structure across firms in different size groups, this study focuses on examining the differences in capital structure for firms facing different degrees of financial constraints.

Other studies similar to this one include Elsas, Flannery, and Garfinkel (2014) and Grullon, Hund, and Weston (2014). Elsas et al. (2014) focused on how the financing of large investments affect leverage. They found evidence in support of trade-off theory and market timing hypothesis, and very little support for pecking order hypothesis. Their study did not have a comparison group; therefore, whether pecking order theory is supported for firms with small investment in their sample is unknown. In addition, there is no evidence in their study linking the size of investment undertaken by a firm to information asymmetry or agency problem.

Grullon et al. (2014) followed Frank and Goyal (2003) procedure and documented evidence that the largest investing firms finance their investment spending differently from other firms. They found that the largest investors' financing behavior follows the pecking order hypothesis. However, they argue that this pattern vanished rapidly as the sample size increases to include firms with small investments. By increasing their sample to include smaller firms, their analysis was converging towards a representative firm framework.

Hence the failure in capital structure model to predict firm behavior may be partly attributed to representative firm framework. In terms of interpretation, Grullon et al. (2014) results are consistent with those of Fama and French (2002), Frank and Goyal (2003) and Brown et al. (2009) and they arise due to information asymmetry. However, the results in Lemmon and Zender (2010) were attributed to debt capacity constraints. Grullon et al. (2014) focused on determining whether the top largest 100 investors behaved differently while this study seeks to estimate the effects of financial constraints on firm financing behavior.

\subsection{Overview of Literature}

Two important messages emerged from the literature. First, in some cases pecking order theory fails in a representative firm framework. However, when the same firms are classified into groups based on differences in information asymmetry, the theory holds for a subset of firms. Second, the support of pecking order theory varies across dimensions such as size, debt rating and credit quality; which are related to information asymmetry and hence financial constraints. Most of the studies that have used these dimensions have come to a common conclusion that pecking order hypothesis does not hold for the subset of firms with severe informational problem and is in fact strongly supported for firms facing lesser informational problems. This conclusion contradicts pecking order hypothesis. Evidence suggests that use of representative firm framework or failure to accurately identify financially constrained firms produce biased estimates of capital structure. Thus, this study posits that financial constraints affects pecking order financing hierarchy and therefore explains pecking order theory reversal.

\section{Empirical Strategy}

\subsection{Research Design}

The evaluation of the impact of financial constraints on firm pecking order financing hierarchy requires comparing the predictions of pecking order theory for firms under different degrees of financial constraints. Taking presence of financial constraints as a treatment, this entails comparing the pecking order prediction under financial constraints with its counter-factual. Counterfactual, in this context, is what would have been the prediction of pecking order hypothesis in the absence of financial constraints. However, counterfactual cannot be observed. In addition, comparing pecking order predictions for firms under different degrees of financial constraints is misleading due to selection bias. Including regressors that determine financial constraint status reduces or eliminate selection bias. This is the approach adopted in this study.

In the context of pecking order theory, the most effective way to use this approach is to allow for the slope and the intercept to vary across the determinants of firm's financial constraint status and capital structure. Applied econometricians have used interaction terms and the dummy to allow for the intercept and slope to vary across sub-samples. This study started with a simple model of $\mathrm{PoH}$ with no financial constraint regime and extended it to factor in financial constraint regimes by use of determinants of financial constraints and a financial contraints dummy. Following Kirui and Wawire (2017), a financial contraints dummy was constructed using age and size of the firm. Age is the number of years a firm has been listed in the securities market while size is the log of tangible assets. 


\subsection{Model Specification}

Under pecking order hypothesis firms prefer internal finances to external capital, and in case internal finances are inadequate, prefer low risk debt to high risk debt, and high risk debt to equity. Thus, in the case of simple pecking order theory any financing deficit should be funded by debt. The model that implements this was proposed by Shyam-Sunder and Myers (1999) and extended by Frank and Goyal (2003). This model can be interpreted as a model of financing behavior and the cumulative financing over time yields the capital structure. The financing deficit can be expressed as:

$$
D E F_{i t}=D I V_{i t}+N I_{i t}+\Delta W_{i t}+C D_{i t}-C F_{i t}
$$

where $D I V_{i t}$ is dividend payments made by firm $i$ in year $t, N I_{i t}$ is the net investment for firm $i$ in year $t$, $\Delta W_{i t}$ is the net change in working capital for firm $i$ in year $t, C D_{i t}$ is current portion of long-term debt for firm $i$ at the beginning of the year $t$ and $C F_{i t}$ is the operating cash flows after interest and taxes for firm $i$ in year $t$. Aggregation in equation (1) involves restricting the coefficients of the various components of financing deficit to one. If this is not the case, then the most appropriate pattern of coefficients should be used. The pecking order hypothesis to be tested is:

$$
\Delta D_{i t}=\alpha+\beta D E F_{i t}+\varepsilon_{i t}
$$

Where $\Delta D_{i t}$ is the amount of debt issued by firm $i$ in year $t$ and $D E F_{i t}$ is the financing deficit for firm $i$ in year $t$. The pecking order hypothesis holds if the constant, $\alpha$, is equal to zero and the pecking order coefficient, $\beta$, is equal to one. Thus, this study takes $\alpha$ and $\beta$ as the parameters that determine the strength of pecking order prediction.

The financing hierarchy for the financially constrained firms is likely to violate the key empirical prediction of pecking order hypothesis and the test based on equation (2) are unable to detect such violations (Chirinko \& Singha, 2000). To address this shortcoming, Frank and Goyal (2003) modified equation (2) by including conventional variables that drive capital structure. Moreover, following Lemmon and Zender (2010) and Agca and Mozumdar (2004) the square of financing deficit is included in equation (2) and equation (3) to capture the concave relationship between changes in debt and financing deficit in the presence of debt capacity constraints as shown by Chirinko and Singha (2000). The modified model with the expected sign is expressed as follows;

$$
\Delta D_{i t}=\alpha_{0}+\beta D E F_{i t}+\gamma D E F_{i t}^{2}+\alpha_{1} \Delta T_{i t}-\alpha_{2} \Delta M t B_{i t}+\alpha_{3} \Delta s_{i t}-\alpha_{4} \Delta P_{i t}+\varepsilon_{i t}
$$

Where $\Delta D_{i t}$ is the amount of debt issued by firm $i$ at time $t, D E F_{i t}$ is the financing deficit for firm $i$ in year $t, \Delta T_{i t}$ stands for change in tangibility of assets for firm $i$ in year $t, \Delta M t B_{i t}$ is the change in market-to-book ratio of for firm $i$ in year $t, \Delta S_{i t}$ is the change in log of sales for firm $i$ in year $t$ and $\Delta P_{i t}$ is the change in profitability for firm $i$ in year $t$. Other variables are as defined earlier. $\alpha^{\prime} s, \beta$ and $\gamma$ are the parameters to be estimated while $\varepsilon$ is the error term.

The coefficient of market-to-book ratio is negative while that of sales is positive. The coefficient of profitability and tangibility are ambiguous. Due to information asymmetry, profitable firms are predicted to have higher leverage. On the other hand, highly profitable firms with few investments, as measured by market to book value, have little debt (Fama \& French, 2002). Few tangible assets are associated with information asymmetry which makes firms to accumulate more debt over time. Alternatively, tangible assets act as collateral hence causing firms with high collateral to have high debt. The coefficient $\gamma$ in equation (3) should be zero or positive if financial constraints are not binding, otherwise it is negative.

To determine whether financial constraint regime is important in capital structure, equation (3) was extended by adding the determinants of financial constraints as regressors. This gives:

$$
\Delta D_{i t}=\alpha_{0}+\beta D E F_{i t}+\gamma D E F_{i t}^{2}+b_{2} Z_{i t}+\alpha_{1} \Delta T_{i t}-\alpha_{2} \Delta M t B_{i t}+\alpha_{3} \Delta s_{i t}-\alpha_{4} \Delta P_{i t}+\varepsilon_{i t}
$$

Where $Z_{i t}$ is a vector of variables for firm $i$ in year $t$ that determine financial constraint status. $\alpha^{\prime} s$ and the vector $b_{2}$ are the parameters to be estimated. Other variables are as defined earlier. A coefficient vector $b_{2}$ that is statistically different from zero implies financial constraints plays a pivotal role in corporate capital structure. However, if $Z_{i t}$ is correlated with the determinants of capital structure, then the coefficients of $Z_{i t}$ might be biased. This problem was mitigated by dropping $Z_{i t}$ from regression equation and instead interacting all the right hand size variables with the financial constraints regime. This gives:

$$
\begin{aligned}
& \Delta D_{i t}=\alpha_{0}+\beta D E F_{i t}+\gamma D E F_{i t}^{2}+\alpha_{1} \Delta T_{i t}-\alpha_{2} \Delta M t B_{i t}+\alpha_{3} \Delta s_{i t}-\alpha_{4} \Delta P_{i t}+b_{3} D_{i t}+b_{4}\left(D_{i t} \times D E F_{i t}\right)+ \\
& b_{5}\left(D_{i t} \times D E F_{i t}^{2}\right)+b_{6}\left(D_{i t} \times \Delta T_{i t}\right)-b_{7}\left(D_{i t} \times \Delta M t B_{i t}\right)+b_{8}\left(D_{i t} \times \Delta s_{i t}\right)-b_{9}\left(D_{i t} \times \Delta P_{i t}\right)+\varepsilon_{i t}
\end{aligned}
$$


where $D_{i t}$ is a dummy that equals one if firm $i$ is financially constrained in time $t$ and zero, otherwise. $\alpha^{\prime} s$ and $b^{\prime} s$ are the parameters to be estimated. Other variables are as defined earlier. The coefficients of interest are $b_{3}$ and $b_{4}$. A positive coefficient of $b_{4}$ significantly not different from one and an insignificant value of $b_{3}$ imply that the prediction of pecking order model is stronger for financially constrained firms. If the subset of firms defined by $D$ equals to 1 is financially constrained, then the coefficient $b_{5}$ should be negative. In this way, this study makes a contribution by introducing a new way of testing for the effects of financial constraints on pecking order prediction. Least squares dummy variable (LSDV) was used in estimation of equation (3), (4) and (5).

\subsection{Data}

This study used data of manufacturing firms that were listed on Nairobi Securities Exchange between 1999 and 2016. The data was collected from published financial statements that companies filed at Capital Markets Authority. Published financial statements consist of balance sheet, income statements and cash flow statements, and are the principal source of the data used in this study. The sample consists of all (13) companies in the manufacturing sector that were listed on the Nairobi Securities Exchange (NSE). To avoid survival bias, data for listed manufacturing companies that entered or exited the NSE between 1999 and 2016, were all included. In addition, observations without data on the variables of interest were dropped. All figures are expressed in 2009 constant prices. Supplementary data on variables not reported in financial statements were obtained from NSE. These included market prices of stocks and the year a company was listed at the NSE. Data on consumer price index were sourced from the World Bank.

\section{Empirical Results}

\subsection{Descriptive Statistics}

The distribution of age and size was used to classifiy firms into two levels of financial constraints. 49 percent of the firms are smaller than 10.2 while 36 percent of the firms are younger 20.5 years. Grouping mature and large firms as financially unconstrained and any other firm as financially constrained give constrained and unconstrained sub-samples constructed by Kirui and Wawire (2017). Table 1 summarizes firms characteristics for the entire sample, constrained and unconstrained sub-samples.

Table 1. Summary statistics

\begin{tabular}{lrrr}
\hline & & \multicolumn{2}{c}{ Constrained Status } \\
\cline { 2 - 3 } Variables & Entire Sample & NFC & 0.5011 \\
\hline$\Delta D$ & 0.3942 & 0.1759 & 1.1098 \\
& 0.9771 & 0.5715 & 149 \\
FC Status & 222 & 73 & 1 \\
& 0.671 & 0 & 0 \\
Age & 0.4709 & 0 & 155 \\
& 231 & 76 & 2.8555 \\
Size & 3.1131 & 3.6011 & 0.8376 \\
& 0.7689 & 0.1411 & 144 \\
Sales & 220 & 76 & 10.4839 \\
& 11.0488 & 12.1865 & 0.9673 \\
Profitability & 1.1794 & 0.6082 & 147 \\
& 220 & 73 & 7.9363 \\
Tangibility & 8.9855 & 11.127 & 6.9722 \\
& 7.2052 & 7.2456 & 149 \\
Market to Book & 222 & 73 & 1.3147 \\
& 1.7372 & 2.5995 & 1.6265 \\
& 2.111 & 2.6677 & 149 \\
& 222 & 73 & 8.8433 \\
& 9.1949 & 9.9124 & 149 \\
& 6.2874 & 6.6462 & 10.0196 \\
& 222 & 73 & 12.2398 \\
& 13.6292 & 20.9968 & 149 \\
\hline
\end{tabular}




\begin{tabular}{lrrr}
\hline Financing Deficit & 0.3299 & 0.0198 & 0.4819 \\
& 1.1531 & 0.6566 & 1.3057 \\
& 222 & 73 & 149 \\
Log of Assets & 10.1455 & 11.5697 & 9.4431 \\
& 1.5876 & 0.6148 & 1.4433 \\
& 221 & 73 & 148 \\
\hline
\end{tabular}

Note. The first column gives the variable name. The second, third and fourth columns give the descriptive statistics for the entire sample, financially unconstrained firms, and financially constrained firms, respectively. For each variable, the first row presents the mean, the second row the standard deviation and the last row presents the number of observations used.

Sources: Author's Computation.

Clearly, firms in different degrees of financial constraint have different characteristics. About 67 percent of the firms report some level of financial constraints. External capital in the form of debt issues for financially constrained firms is more than twice the level for unconstrained firms. This suggests that the financial constraints in the sample considered here is not due to quantity rationing. Quantity constraints results in lower debt issues for financially constrained firms relative to unconstrained firms. On the other hand, price constraints increases the cost of funds since the firms face a higher risk premium (Note 5), without locking firms out of the capital market. This results in a wider wedge between the opportunity cost of internal funds and the cost of debt and the wider wedge the higher the value the firm will transfer to debt-holders if it decides to use debt.

Despite accounting for less than 30 percent of debt issued, unconstrained firms hold more than half of the tangible assets that can be pledged as security against borrowings. This suggests that the decision to issue debt is driven by the value the firm will transfer to debt-holders if it decides to use debt, which is higher the higher the wedge between the cost of internal funds and the cost of debt. Thus, the lower level of debt issue by unconstrained firms cannot be due to financial constraints since these firms have more tangible assets that they can pledge as security for more debt. Moreover, market to book value of assets for unconstrained firms is about twice that of constrained firms. This implies that unconstrained firms have low sunk cost than constrained firms, which is most likely to arise from differences in 'currency of technology' content in assets or more generally the quality of assets.

Furthermore, financially constrained firms have higher level of financing deficit compared to the unconstrained counterparts. High financing deficit is linked to high debt issue among financially constrained firms. Similarly, lower financing deficit for unconstrained firms explain the lower level of debt issue. It also explains why these firms have higher tangible assets yet they have low level of debt issue. Higher profitability seems to result in higher level of cash flow, which reduces the financing gap for financially unconstrained firms. On the other hand, an average constrained firm has a level of profitability which is almost half that of unconstrained firms. Thus, high profitability and hence high level of cash flow reduce reliance on debt and hence ease financial constraints.

\subsection{Empirical Pecking Order Tests}

Pecking order prediction was examined by use of Q-Q plot. Non-parametric tests were used to examine differences in the distribution of firms' financing of capital expenditure across the various sources of funds: internal funds and financing of funds flow deficit using debt funds and equity funds. The prediction was also examined by estimating the pecking order model and the determinants of financial constraints and a dummy, which takes one if financially constrained and zero otherwise. Quantile-quantile $(\mathrm{Q}-\mathrm{Q})$ plots is a graphical technique for determining if two data sets come from a population with a common distribution. If the data comes from a population with a common distribution, then the data-points should lie close to the $45^{0}$ diagonal line from origin. Figure 1 graphs the $\mathrm{Q}-\mathrm{Q}$ plot. 

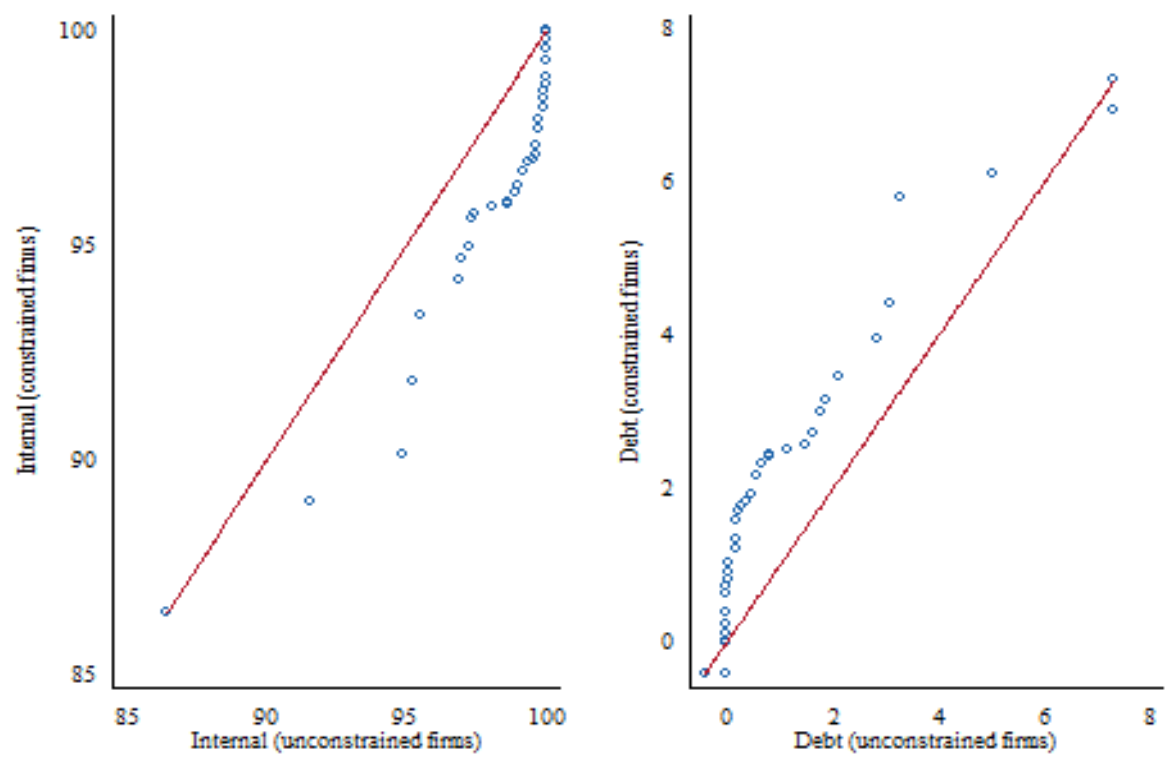

Figure 1. Financing pattern and financial constraints

Source: Author's calculation based on published financial statements.

Overall the Q-Q graphs show that constrained and unconstrained firms exhibit differences in the use of debt and internal funds. Furthermore, the clustering suggests the presence of outliers but the outliers problem is not severe. The Q-Q plot for internal funds and debt depicts differences in the use of internal and debt funds. The Q-Q plots for internal finance are skewed to the right. That is, constrained firms relative to unconstrained firms use less internal finance in their capital expenditure. On the other hand, the Q-Q plot for debt is skewed to the left implying that constrained firms relative to unconstrained firms are biased towards using more debt funds whenever they use external capital. Pecking order models predict that if capital expenditure exceeds internal funds, then the resulting fund flow deficit should be funded by debt due to cost advantage (Note 6). Financially constrained firms exhibit financing pattern that conforms to pecking order theory than do financially unconstrained firms.

Non-parametric Wilcoxon-Mann-Whitney test showed a significant difference between the underlying distributions of the internal and debt funds of constrained firms and the internal and debt funds of unconstrained firms $(z=2.173$, Prob $>|z|=0.0298$ for internal funds and $z=-2.170$, Prob $>|z|=0.0300$ for debt funds). Thus, this statistically significant result gives evidence of significant differences between financing behaviour of financially constrained firms and financially unconstrained firms. The performance of prediction of pecking order hypothesis for the sample considered in this study is examined by use of regression techniques.

Table 2 reports the estimation results for the pecking order model for the basic and extended models under the assumptions of no financial constraints regimes.

Table 2. Baseline Pecking order estimation results

\begin{tabular}{|c|c|c|c|c|}
\hline \multirow[b]{3}{*}{ Variables } & (1) & (2) & (3) & (4) \\
\hline & \multicolumn{2}{|c|}{$\underline{\text { Shyam-Sunder and Myers }}$} & \multicolumn{2}{|c|}{ Frank and Goyal } \\
\hline & Basic & Extended & Basic & Extended \\
\hline \multirow[t]{2}{*}{ Financing Deficit } & $0.4833^{* *}$ & $0.1625^{* *}$ & $0.4812 * *$ & $0.1387 *$ \\
\hline & $(0.186)$ & $(0.073)$ & $(0.186)$ & $(0.066)$ \\
\hline \multirow[t]{2}{*}{ Sales } & & & $-0.0298^{*}$ & -0.0134 \\
\hline & & & $(0.016)$ & $(0.012)$ \\
\hline \multirow[t]{2}{*}{ Profitability } & & & -0.0212 & -0.0693 \\
\hline & & & $(0.080)$ & $(0.058)$ \\
\hline \multirow[t]{2}{*}{ Tangibility } & & & 0.0338 & -0.0005 \\
\hline & & & $(0.031)$ & $(0.017)$ \\
\hline \multirow[t]{2}{*}{ Market to Book } & & & 0.0068 & $0.0085^{*}$ \\
\hline & & & $(0.005)$ & $(0.004)$ \\
\hline
\end{tabular}




\begin{tabular}{|c|c|c|c|c|}
\hline Financing Deficit sq. & & $\begin{array}{r}0.1526^{* * * *} \\
(0.025)\end{array}$ & & $\begin{array}{r}0.1615 * * * \\
(0.027)\end{array}$ \\
\hline Constant & $\begin{array}{r}0.0014 \\
(0.151)\end{array}$ & $\begin{array}{l}-0.0161 \\
(0.093)\end{array}$ & $\begin{array}{l}-0.0301 \\
(0.185)\end{array}$ & $\begin{array}{r}0.1272 \\
(0.102)\end{array}$ \\
\hline Observations & 222 & 222 & 222 & 222 \\
\hline R-squared & 0.45 & 0.64 & 0.46 & 0.65 \\
\hline Number of Firms & 13 & 13 & 13 & 13 \\
\hline PoH test & 16.45 & 78.39 & 7.27 & 156.44 \\
\hline
\end{tabular}

Note. The baseline model presents the estimation results for the pecking order model under the assumptions of no financial constraints regimes. The basic model reports the results of the original models of Shyam-Sunder and Myers (1999) and Frank and Goyal (2003) while the extended model includes financing deficit squared to capture non-linearities in debt capacity constraints. The levels of significance are: * $<<0.1 ; * *$ $\mathrm{p}<0.05 ; * * * \mathrm{p}<0.01$. Standard errors are in parenthesis below the coefficients. The test for pecking order hypothesis was implemented by F-test and the results for this test are presented in the last row; under $\mathrm{POH}$ test.

Source: Author's calculation based on published company financial statements.

The results conform, to a great extent, to the expectations in terms of sign (see for instance: Frank \& Goyal, 2003). With the exception of the coefficient of sales and market to book, all the coefficients have the expected signs. Under Shyam-Sunder and Myers (1999) specification, the pecking order hypothesis was rejected. This also applies to Frank and Goyal (2003) specification. The positive and significant coefficient of financing deficit squared suggests presence of debt capacity constraints. The criticism of Chirinko and Singha (2000) on Shyam-Sunder and Myers (1999) approach does not apply to the results of this study since equity funds were rarely used by firms in the sample used in this study (Note 7). Extending the baseline model by including the determinants of financial constraints gives the results presented in Table 3 below. If financial constraints have no effects on capital structure decisions, then the additional variables should be insignificant. Table 3 presents results for the tests of the effects of financial constraints.

Table 3. Pecking order estimation results in the presence of financial constraints

\begin{tabular}{|c|c|c|c|c|}
\hline \multirow[b]{3}{*}{ Variables } & \multirow{2}{*}{\multicolumn{2}{|c|}{$\begin{array}{c}(1) \\
\text { Shyam-Sunder and Myers }\end{array}$}} & (3) & (4) \\
\hline & & & \multicolumn{2}{|c|}{ Frank and Goyal } \\
\hline & Basic & Extended & Basic & Extended \\
\hline \multirow[t]{2}{*}{ Financing Deficit } & $0.4324 * * *$ & $0.1494 * * *$ & $0.4383 * * *$ & $0.1216^{* * *}$ \\
\hline & $(0.049)$ & $(0.052)$ & $(0.052)$ & $(0.054)$ \\
\hline \multirow[t]{2}{*}{ Sales } & & & -0.0075 & 0.002 \\
\hline & & & $(0.023)$ & $(0.019)$ \\
\hline \multirow[t]{2}{*}{ Profitability } & & & -0.0121 & -0.0642 \\
\hline & & & $(0.062)$ & $(0.051)$ \\
\hline \multirow[t]{2}{*}{ Tangibility } & & & 0.0071 & -0.0167 \\
\hline & & & $(0.021)$ & $(0.017)$ \\
\hline \multirow[t]{2}{*}{ Market to Book } & & & 0.0056 & 0.0081 \\
\hline & & & $(0.007)$ & $(0.006)$ \\
\hline \multirow[t]{2}{*}{ Age } & -0.1331 & 0.0399 & -0.1057 & 0.0192 \\
\hline & ( 0.199$)$ & $(0.166)$ & ( 0.209$)$ & $(0.172)$ \\
\hline \multirow[t]{2}{*}{ Size } & $0.3649 * * *$ & $0.2018 * *$ & $0.3380^{* * *}$ & $0.2108^{* * *}$ \\
\hline & $(0.096)$ & $(0.082)$ & $(0.112)$ & $(0.093)$ \\
\hline \multirow[t]{2}{*}{ Financing Deficit sq. } & & $0.1448 * * *$ & & $0.1559 * * *$ \\
\hline & & $(0.016)$ & & ( 0.017) \\
\hline \multirow[t]{2}{*}{ Constant } & $-3.7212 * * *$ & $-2.3579 * *$ & $-3.4944 * *$ & $-2.2527 * *$ \\
\hline & ( 1.179$)$ & $(0.991)$ & ( 1.372$)$ & ( 1.130$)$ \\
\hline Observations & 215 & 215 & 215 & 215 \\
\hline R-squared & 0.49 & 0.65 & 0.49 & 0.66 \\
\hline Number of Firms & 13 & 13 & 13 & 13 \\
\hline PoH test & 65.99 & 136.19 & 59.11 & 132.34 \\
\hline
\end{tabular}

Note. The results of the baseline model and the model with financial constraints variables are similar. The levels of significance are: $* \mathrm{p}<0.1$; $* * \mathrm{p}<0.05 ; * * * \mathrm{p}<0.01$. Standard errors are in parenthesis below the coefficients. The test for pecking order hypothesis was implemented by F-test and the results for this test are presented in the last row; under $\mathrm{POH}$ test.

Source: Author's calculation based on published company financial statements. 
Unlike in the baseline model, the effects of conventional variables are entirely wiped out by the effects of financing deficit. Furthermore, pecking order theory was rejected in all cases. Size is significant, which suggests that financial constraints are important in capital structure decisions. The results in Table 3 are likely to be biased since age and size might be correlated with variables such as tangibility, sales and profitability. In addition, the significant intercept suggests misspecification of the models. These problems were addressed by introducing a dummy, which took the value of one if a firm was financially constrained and zero, otherwise and then interacting it with the right hand side variables of the pecking order equation. This definition ensured that the first six coefficients were the coefficients of financially unconstrained firms; the sub-sample under which pecking order hypothesis should be less strong, if it holds. And, the next six coefficients gave the differences in coefficients on each variable arising from differences in the level of financial constraints. Table 4 reports the estimates for pecking order model under different financial constraints regimes.

Table 4. Extended pecking order in the presence of financial constraint

\begin{tabular}{|c|c|c|c|c|}
\hline \multirow[b]{3}{*}{ Variable } & $(1)$ & (2) & (3) & (4) \\
\hline & \multicolumn{2}{|c|}{ Shyam-Sunder and Myers } & \multicolumn{2}{|c|}{ Frank and Goyal } \\
\hline & Basic & Extended & Basic & Extended \\
\hline \multirow[t]{2}{*}{ Financing Deficit } & 0.0714 & 0.0986 & 0.0653 & 0.0845 \\
\hline & $(0.096)$ & $(0.080)$ & $(0.102)$ & $(0.085)$ \\
\hline \multirow[t]{2}{*}{ Sales } & & & -0.0353 & -0.0307 \\
\hline & & & $(0.029)$ & $(0.025)$ \\
\hline \multirow[t]{2}{*}{ Profitability } & & & -0.0127 & -0.0219 \\
\hline & & & $(0.077)$ & $(0.064)$ \\
\hline \multirow[t]{2}{*}{ Tangibility } & & & 0.0308 & 0.0307 \\
\hline & & & $(0.032)$ & $(0.028)$ \\
\hline \multirow[t]{2}{*}{ Market to Book } & & & 0.0012 & 0.0018 \\
\hline & & & $(0.009)$ & $(0.007)$ \\
\hline \multirow[t]{2}{*}{ ZxFinancing Deficit } & $0.5057 * * *$ & 0.0014 & $0.5149 * * *$ & 0.0091 \\
\hline & $(0.104)$ & $(0.102)$ & $(0.111)$ & $(0.108)$ \\
\hline \multirow[t]{2}{*}{ ZxSales } & & & -0.0191 & 0.0059 \\
\hline & & & $(0.027)$ & $(0.023)$ \\
\hline \multirow[t]{2}{*}{ ZxProfitability } & & & -0.0043 & -0.0569 \\
\hline & & & $(0.094)$ & $(0.078)$ \\
\hline \multirow[t]{2}{*}{ ZxTangibility } & & & 0.0118 & -0.0409 \\
\hline & & & $(0.039)$ & $(0.035)$ \\
\hline \multirow[t]{2}{*}{ ZxMarket to Book } & & & $0.0193 *$ & 0.0107 \\
\hline & & & $(0.012)$ & $(0.010)$ \\
\hline \multirow[t]{2}{*}{ Unconstrained } & -0.2205 & -0.1884 & -0.0351 & 0.0808 \\
\hline & $(0.175)$ & $(0.150)$ & $(0.238)$ & $(0.198)$ \\
\hline \multirow[t]{2}{*}{ Financing Deficit sq. } & & -0.0101 & & -0.0255 \\
\hline & & -0.0444 & & -0.0476 \\
\hline \multirow[t]{2}{*}{ ZxFinancing Deficit sq. } & & $0.1866^{* * *}$ & & $0.2117 * * *$ \\
\hline & & $(0.049)$ & & $(0.052)$ \\
\hline \multirow[t]{2}{*}{ Constant } & 0.2496 & 0.3057 & 0.2404 & 0.2435 \\
\hline & $(0.246)$ & $(0.208)$ & $(0.260)$ & $(0.217)$ \\
\hline Observations & 222 & 222 & 222 & 222 \\
\hline Number of Firms & 13 & 13 & 13 & 13 \\
\hline PoH test for NFC & 96.22 & 22.8 & 84.98 & 20.44 \\
\hline $\mathrm{PoH}$ test for $\mathrm{FC}$ & 73.17 & 96.04 & 67.63 & 91.38 \\
\hline Interacted & 23.92 & 15.26 & 30.04 & 5.22 \\
\hline
\end{tabular}

Note. Like in the preceding tables, Table 4 present the results of the basic model and the extended model augmented with proxy for non-linearities in debt capacity constraints for each approach. The levels of significance are: $* p<0.1 ; * * p<0.05 ; * * * p<0.01$. Standard errors are in parenthesis below the coefficients. The test for pecking order hypothesis was implemented by F-test and the results for this test are presented in the last row; under POH test.

Source: Author's calculation based on published company financial statements. 
As hypothesized, the effects of all conventional factors are almost wiped out entirely. Only ZxMarket to Book is significant at 10 percent level of significance when the measure of non-linearities in debt capacity constraints is excluded. With the inclusion of non-linearities in debt capacity constraints this disappears. ZxFinancing Deficit is significant at 1 percent when non-linearities in debt capacity constraints are excluded. ZxFinancing Deficit squared is positive and significant at 5 percent implying that financially constrained firms are debt capacity constrained. In contrast, unconstrained firms are not debt capacity constrained.

The joint significance test of the interacted right hand side variables of the pecking order test equations are 23.92 and 30.04 for the basic model under Shyam-Sunder and Myers (1999) and Frank and Goyal (2003), respectively. These are statistically significant at 1 percent. When the proxy for debt capacity constraints is included, the test statistics are 15.26 and 5.22 under Shyam-Sunder and Myers (1999) and Frank and Goyal (2003) model, respectively and are significant at 1 percent and 10 percent, respectively. Thus, the inclusion of debt capacity constraints do not eliminate the need to take into consideration financial constraints, and therefore the results of Lemmon and Zender (2010) does not fully account for financial constraints.

The coefficient of financing deficit increases slightly when the non-linearities in debt capacity constraints were included. In contrast, it is lower when it is excluded. The derivative of the dependent variable with respect to financing deficit shows that the coefficients of financing deficit for financially constrained firms is different from that of financially unconstrained firms. The test for the differences in coefficients of financing deficit for financially constrained and unconstrained firms using the results in column labelled (1) and (3) give Chi-square statistics of 23.81 and 10.17, respectively. These are statistically significant at 1 percent and it shows that the coefficients for financing deficit vary with financial constraint status. On the other hand, a similar test for the columns labelled (2) and (4) give Chi-square statistics of 21.58 and 11.88, respectively. These results are statistically significant and these indicate that when debt capacity constraints are controlled for, the coefficients for financing deficit remain different across financial constraint statuses. Thus, financial constraints are different from debt capacity constraints.

\section{Discussion}

Pecking order hypothesis is rejected for all specification and for both constrained and unconstrained firms. When non-linearities in debt capacity constraints is omitted and judging by the sizes (Note 8) of the pecking order tests statistics, pecking order prediction is stronger for financially unconstrained firms than for financially constrained firms. Given that financially constrained firms consists of firms whose informational problems looms large, then this lead to the conclusion that pecking order theory holds for subset of firms with less informational problem and is weaker or do not hold for the subset of firms with severe informational problem.

This conclusion is similar to that of Frank and Goyal (2003) and Fama and French (2002). However, introducing non-linearities in debt capacity constraints reverses these results and conclusion. Hence, the explanation for reversal of prediction of pecking order theory lies in controlling for non-linearities in debt capacity constraints and allowing for financial constraints regimes. This study attributes these results to the wedge between the cost of internal and external funds, in particular debt. The higher the wedge between the cost of internal funds and the cost of debt, the higher the value the firm will transfer to debt-holders if it decides to use debt funds and the more severe financial constraints is. Since the goal of the firm is to maximize value for its shareholders, then it is unlikely to issue debt in such a case. Debt will only be issued by firms as a last resort.

But, do financial constraints explain pecking order reversal for small-high growth firms? The average size of financially constrained firms in the sample used in this study is 9.4 compared to 11.6 for unconstrained firms. The growth rate of turnover for financially constrained firms is about 6.1 percent compared to 3.8 percent for financially unconstrained firms. Thus, financially constrained firms are small and exhibit high growth. Therefore, the violation of pecking order prediction by small high growth firms in Fama and French (2002) sample arose due to failure to control for non-linearities in debt capacity constraints and financial constraints regimes. Although firms can have excess debt capacity, the cost of debt relative to the cost of internal funds is important and therefore drives financing decisions. Thus, price constraints are more important to all firms while quantity constraints also affect financially constrained firms. This explains debt issues and financial constraint status of the firms studied. Similar evidence has been documented by Faulkender and Petersen (2006) who found that the cost of debt drives financing decisions. Unlike this study which looked at the cost of debt relative to the cost of internal funds, their study considered cost of debt.

\section{Conclusion}

This paper studied the effects of financial constraints on firm capital structure. This was implemented by interacting a financial constraints dummy with the right-hand side variables of pecking order test equation. 
Internal finance was found to be a major source of finance for capital expenditure for both unconstrained and constrained firms. However, the propensity to use internal funds is lower for constrained firms than for unconstrained firms. This could arise if internal funds are lower relative to capital expenditure in the case of constrained firms. Furthermore, unconstrained firms accounts for about 30 percent of debt issued despite holding more than half of the tangible assets and this suggests that the decision to issue debt is driven by the value the firm will transfer to debt-holders if it decides to use debt.

Pecking order was rejected for all specification considered and for both constrained and unconstrained firms. Financing behavior varies with financial constraints status. Thus, the effects of financial constraints on capital structure decisions cannot be ruled out. The more severe financial constraints are the wider the wedge between the cost of debt and the opportunity cost of internal funds. Firms facing a wider wedge do not issue debt; if they do so then they will be transferring substantial value of the firm to debt-holders. This is the main cause of the results that contradict pecking order theory. When we controlled for nonlinearities in debt capacity constraints and allowed for financial constraint regimes pecking order hypothesis return hypothetically correct results. In order to improve access to capital and hence debt utilization, policies should aim at easing access to capital, for instance, by broadening the scope of assets that can be pledged as collateral and providing incentives to analysts who cover small and young firms so as to increase flow of information to providers of external capital. This will lead to reduction in the wedge between the cost of external and internal funds and hence increase in debt utilization.

\section{Acknowledgments}

Comments from Prof. Nassio Masinke and the seminar participants at the 2014 African Economic Research Consortium (AERC) bi-annual workshop at Accra, Ghana and Lusaka, Zambia are acknowledged. Financial support from the AERC is gratefully acknowledged. Any errors are my own.

\section{References}

Agca, S., \& Mozumdar, A. (2004). Firm size, debt capacity, and corporate financing choices. Debt Capacity, and Corporate Financing Choices (December 2004). https://doi.org/10.2139/ssrn.687369

Chirinko, R. S., \& Singha, A. R. (2000). Testing static tradeoff against pecking order models of capital structure: A critical comment. Journal of Financial Economics, 58(3), 417-425. https://doi.org/10.1016/S0304-405X(00)00078-7

Elsas, R., Flannery, M. J., \& Garfinkel, J. A. (2014). Financing major investments: Information about capital structure decisions. Review of Finance, 18(4), 1341-1386. https://doi.org/10.1093/rof/rft036

Faulkender, M., \& Petersen, M. A. (2006). Does the source of capital affect capital structure? Review of Financial Studies, 19(1), 45-79. Retrieved March 13, 2015 from http://rfs.oxfordjournals.org/content/19/1/45.short

Fazzari, S. M., Hubbard, R. G., Petersen, B. C., Blinder, A. S., \& Poterba, J. M. (1988, January). Financing constraints and corporate investment. Brookings Papers on Economic Activity, (1), 141-206. https://doi.org/10.2307/2534426

Frank, M. Z., \& Goyal, V. K. (2003). Testing the pecking order theory of capital structure. Journal of Financial Economics, 67(2), 217248. https://doi.org/10.1016/S0304-405X(02)00252-0

Grullon, G., Hund, J., \& Weston, J. P. (2014). Investment concentration and the importance of cash flow. $\begin{array}{lllll}\text { Unpublished. } & \text { Retrieved } & \text { December } & 23, & \end{array}$ http://www.ruf.rice.edu/ westonj/wp/investment.pdf(00000)

Hennessy, C. A., \& Whited, T. M. (2007). How costly is external financing? Evidence from a structural estimation. The Journal of Finance, 62(4), 1705-1745. https://doi.org/10.1111/j.1540-6261.2007.01255.x

Jensen, M. C., \& Meckling, W. H. (1976). Theory of the firm: Managerial behavior, agency costs, and ownership structure. Journal of Financial Economics, 3(4), 305-360. https://doi.org/10.1016/0304-405X(76)90026-X

Kirui, B. K., \& Wawire, H. W. N. (2017). Measures of Financial Constraints in Kenya. International Journal of Economics and Financial Issues (forthcoming).

Korajczyk, R. A., \& Levy, A. (2003). Capital structure choice: Macroeconomic conditions and financial $\begin{array}{lllll}\text { constraints. Journal of } & \text { Financial }\end{array}$ https://doi.org/10.1016/S0304-405X(02)00249-0

Lamont, O. (1997). Cash flow and investment: Evidence from internal capital markets. The Journal of Finance, 
52(1), 83-109. https://doi.org/10.1111/j.1540-6261.1997.tb03809.x

Myers, S. C. (1977). Determinants of corporate borrowing. Journal of Financial Economics, 5(2), 147-175. https://doi.org/10.1016/0304-405X(77)90015-0

Myers, S. C. (1984). The capital structure puzzle. The Journal of Finance, 39(3), 574-592. https://doi.org/10.1111/j.1540-6261.1984.tb03646.x

Myers, S. C., \& Majluf, N. S. (1984). Corporate financing and investment decisions when firms have information that investors do not have. Journal of Financial Economics, 13(2), 187-221. https://doi.org/10.1016/0304-405X(84)90023-0

Rauh, J. D., \& Sufi, A. (2010). Capital structure and debt structure. Review of Financial Studies, 4242-4280. https://doi.org/10.1093/rfs/hhq095

Shivdasani, A., \& Stefanescu, I. (2009). How do pensions affect corporate capital structure decisions? Review of Financial Studies, $94 . \quad$ Retrieved March 25, 2015 from http://rfs.oxfordjournals.org/content/early/2009/11/02/rfs.hhp094.short(00084)

Shyam-Sunder, L., \& Myers, S. C. (1999). Testing static tradeoff against pecking order models of capital

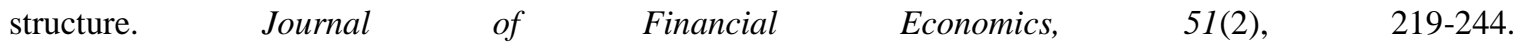
https://doi.org/10.1016/S0304-405X(98)00051-8

Stiglitz, J. E., \& Weiss, A. (1981). Credit rationing in markets with imperfect information. The American Economic Review, 393-410. Retrieved December 23, 2014 from http://www.jstor.org/stable/1802787(12407)

Yang, J. (2014). Equity and debt financing constraints. Available at SSRN 1785066. Retrieved December 23, 2014 from http://papers.ssrn.com/sol3/papers.cfm?abstract_id=1785066(00000)

Modigliani, F., \& Miller, M. H. (1958, June). The cost of capital, corporation finance and the theory of investment. The American Economic Review, 48(3), 261-297. Retrieved December 23, 2014 from http://www.jstor.org/stable/1809766(14089)

Modigliani, F., \& Miller, M. H. (1963, June). Corporate income taxes and the cost of capital: A correction. The American Economic Review, 53(3), 433-443. Retrieved December 23, 2014 from http://www.jstor.org/stable/1809167(04864)

Ross, S. A. (1977, April). The determination of financial structure: The incentive-signalling approach. The Bell Journal of Economics, 8(1), 23-40. Retrieved December 23, 2014 from http://www.jstor.org/stable/3003485(03539)

Bond, S., \& Meghir, C. (1994, April). Dynamic investment models and the firm's financial policy. The Review of Economic Studies, 61(2), 197-222. https://doi.org/10.2307/2297978

Chirinko, R. S., \& Schaller, H. (1995, May). Why does liquidity matter in investment equations? Journal of Money, Credit and Banking, 27(2), 527-548. https://doi.org/10.2307/2077882

Rajan, R. G., \& Zingales, L. (1995, December). What do we know about capital structure? Some evidence from international data. The Journal of Finance, 50(5), 1421-1460. https://doi.org/10.2307/2329322

Fama, E. F., \& French, K. R. (2002, April). Testing trade-off and pecking order predictions about dividends and debt. The Review of Financial Studies, 15(1), 1-33. Retrieved December 23, 2014 from http://www.jstor.org/stable/2696797(02126)

Brown, J. R., Fazzari, S. M., \& Petersen, B. C. (2009, February). Financing innovation and growth: Cash flow, external equity, and the 1990s R\&D boom. The Journal of Finance, 64(1), 151-185. Retrieved December 23, 2014 from http://www.jstor.org/stable/20487966(00417)

Lemmon, M. L., \& Zender, J. F. (2010, October). Debt capacity and tests of capital structure theories. The Journal of Financial and Quantitative Analysis, 45(5), 1161-1187. Retrieved December 23, 2014 from http://www.jstor.org/stable/27919560 (00367)

\section{Notes}

Note 1. Debt capacity constraints can arise if firms do not have pledge-able assets.

Note 2. Debt capacity is inferred from excess capacity (over and above existing debt contracts) in terms of 
uncommitted future cash flows or tangible assets that a firm can pledge as security to obtain debt.

Note 3. Yang (2014) approach is general that it cannot be interpreted in the context of pecking order theory.

Note 4. Trade-off theory, however, considers whether there is target leverage and if firms' capital structure tends to evolve towards this target leverage level.

Note 5. This might arise if subsequent debts do not rank pari passu with debt issued earlier or because of negative pledges, both of which results in increased risk.

Note 6. Lower informational costs and tax shield benefits reduces the cost of debt relative to equity.

Note 7. Excluding these equity issues does not affect the results.

Note 8. If the size of Chi-square statistics reflects the deviation of observed relationship from expected relationship for pecking order hypothesis to hold, then a higher value would mean a substantial deviation. Since the specification of the model and therefore the degrees of freedom are the same, it is reasonable to compare the Chi-square statistics of the not constrained and constrained sub-samples.

\section{Copyrights}

Copyright for this article is retained by the author(s), with first publication rights granted to the journal.

This is an open-access article distributed under the terms and conditions of the Creative Commons Attribution license (http://creativecommons.org/licenses/by/4.0/). 